\title{
Key insights for the future of urban ecosystem services research
}

\author{
$\underline{\text { Peleg Kremer }}^{1,2}, \underline{\text { Zoé Hamstead }}^{3}, \underline{\text { Dagmar Haase }}^{4,5}$, Timon McPhearson $^{6}, \underline{\text { Niki Frantzeskaki }}^{7}, \underline{\text { Erik Andersson }}^{8}, \underline{\text { Nadja Kabisch }}^{4,9,10}$, \\ Neele Larondelle $^{4,11}$, Emily L. Rall ${ }^{12}$, Annette Voigt ${ }^{13}$, Francesc Baró ${ }^{14}$, Christine Bertram $^{15}$, Erik Gómez-Baggethun $^{16,17}$, Rieke $^{14}$

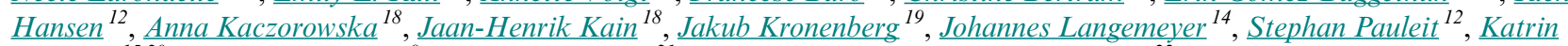

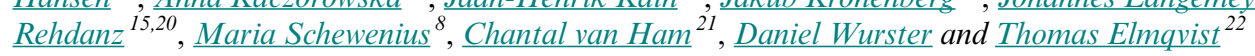

ABSTRACT. Understanding the dynamics of urban ecosystem services is a necessary requirement for adequate planning, management, and governance of urban green infrastructure. Through the three-year Urban Biodiversity and Ecosystem Services (URBES) research project, we conducted case study and comparative research on urban biodiversity and ecosystem services across seven cities in Europe and the United States. Reviewing > 50 peer-reviewed publications from the project, we present and discuss seven key insights that reflect cumulative findings from the project as well as the state-of-the-art knowledge in urban ecosystem services research. The insights from our review indicate that cross-sectoral, multiscale, interdisciplinary research is beginning to provide a solid scientific foundation for applying the ecosystem services framework in urban areas and land management. Our review offers a foundation for seeking novel, nature-based solutions to emerging urban challenges such as wicked environmental change issues.

Key Words: biodiversity; social-ecological systems; urban ecology; urban ecosystem services; urban green infrastructure; urban liveability; urban planning

\section{INTRODUCTION}

Urban ecosystem services (ES) are produced and consumed within the context of autonomous but interacting social, ecological, economic, and technological systems. Understanding how these systems influence the availability of urban ES is critical for planning, managing, and governing urban ecosystems (Gomez-Baggethun et al. 2013a, McPhearson et al. 2016).

The three-year Urban Biodiversity and Ecosystem Services (URBES) research project assessed urban ES and biodiversity in seven cities in Europe and the United States. Through understanding urban places as complex social-ecological systems, the project applied multiscale interdisciplinary approaches and integrated assessment methods. Working in Berlin, Rotterdam, Salzburg, Stockholm, Barcelona, Helsinki, and New York City (NYC), URBES researchers (1) assessed ES performance in cities at a range of scales from patches to the continent, (2) explored planning instruments and governance of urban ES, and (3) engaged in knowledge exchange among scientists, planners and other government officials, nongovernmental organization representatives, and the general public.

Here, we highlight the cumulative results and new understandings of urban ES generated by the URBES project. We analyzed the aggregate results of the project using a two-step process. First, URBES members participated in a survey and one-day workshop in which they reflected on the collective themes of the project. We then used the results of this workshop along with a review of the project's $>50$ published papers to develop a synthesis of the project as a whole. We present seven insights supported by the URBES project research, including critical achievements and remaining gaps.

1. Land-cover and land-use based indicators are convenient for evaluating ES but have limitations for comparative research in urban areas and may discourage new empirical, field-based research.

2. Understanding relationships and mismatches between supply and demand for urban ES requires cross-boundary and cross-scale considerations.

3. Urban ES are mediated by nonecological elements, including physical infrastructure, technology, social practices, and the cultural contexts in which people experience human-environment relations. This issue is particularly important in the urban realm, where high densities of people and of mediation elements necessitate nuanced study of the relationships among them.

4. Urban nature provides an opportunity for people in cities to connect with nature. Cultural ES that come about through this connection to nature bring the diverse values and

${ }^{1}$ Department of Geography and the Environment, Villanova University, ${ }^{2}$ Tishman Environment and Design Center, The New School, ${ }^{3}$ Milano School of International Affairs, Management and Urban Policy, The New School, ${ }^{4}$ Humboldt-Universität zu Berlin, Department of Geography, ${ }^{5}$ Helmholtz Centre for Environmental Research - UFZ, Department of Computational Landscape Ecology, ${ }^{6}$ Urban Ecology Lab, Environmental Studies Program, The New School, ${ }^{7}$ DRIFT, Faculty of Social Sciences, Erasmus University Rotterdam, ${ }^{8}$ Stockholm Resilience Centre, Stockholm University, ${ }^{9}$ Helmholtz Centre for Environmental Research - UFZ, Department of Ecosystem Services, ${ }^{10}$ German Centre for Integrative Biodiversity Research (iDiv) Halle-Jena-Leipzig, ${ }^{11}$ Potsdam Institute for Climate Impact Research, ${ }^{12}$ Technical University of Munich, Chair for Strategic Landscape Planning and Management, ${ }^{13}$ Department of Geography and Regional Studies, Alpen-Adria-Universität, ${ }^{14}$ Institute of Environmental Science and Technology (ICTA), Universitat Autònoma de Barcelona (UAB), ${ }^{15}$ Kiel Institute for the World Economy, Research Area The Environment and Natural Resources, ${ }^{16}$ Norwegian Institute for Nature Research (NINA), ${ }^{17}$ Department of International Environment and Development Studies (Noragric), Norwegian University of Life Sciences (NMBU), ${ }^{18}$ Department of Architecture, Chalmers University of Technology, ${ }^{19}$ Department of International Economics, University of Lodz, ${ }^{20}$ University of Kiel, Department of Economics, ${ }^{21}$ IUCN - International Union for Conservation of Nature, ${ }^{22}$ Stockholm Resilience Center, Stockholm University 
meanings people find in nature to light and enable, inform, and substantiate discussion about environmental potentials and challenges in cities.

5. Relationships between biodiversity and ES in urban areas are unclear, lack evidence, and require new data and empirical research.

6. Effective implementation of the urban ES concept in practice requires overcoming disciplinary barriers, bridging science-policy-governance gaps, and aligning the ES scientific concept with existing planning frameworks and tools.

7. Cross-city comparisons are fundamental for understanding the drivers of ecosystem structure, functioning, and processes, as well as for differentiating between dynamics that are locally unique vs. those which are generalizable to multiple urban contexts across the globe.

\section{RESEARCH-BASED INSIGHTS FOR THE FUTURE OF URBAN ECOSYSTEM SERVICES RESEARCH}

\section{Insight 1: use of indicators}

Land-cover and land-use indicators are convenient for evaluating ecosystem services but may be problematic as proxies for urban ecosystem services. In a quantitative review of literature relating to urban ES, we found that local and regional studies primarily model regulating urban ES using land-use or land-cover classes as indicators. These indicators are used as proxies for ecological, biogeochemical, or biophysical functions, and thus, as proxies for the performance of ecosystems in sustaining services for humans (Haase et al. 2014b). Similarly, many URBES studies used landuse and land-cover data as proxies to estimate ES capacity, flow, and demand. This creates a number of challenges for the field of urban ES estimation in cities and urban regions. Many of these proxies and indicators are simple to generate and widely available to researchers from existing data bases; they are derived from empirical studies that establish relationships between land use or land cover and ES potential for given study areas. In the URBES project, we used this approach to perform single case studies (McPhearson et al. 2013a, Larondelle et al. 2014a, RodríguezRodríguez et al. 2015, Kain et al. 2016) as well as larger cross-city comparisons (Larondelle and Haase 2013, Larondelle et al. $2014 a$ ). However, because of a legacy of nonurban empirical field work, differences in urban morphologies, and urban heterogeneity, land-use and land-cover based proxies and ES indicators may have limited applicability in urban areas and limited transferability from one city to another (e.g., Larondelle and Haase 2013, Kain et al. 2016) for several reasons. First, cities and their metropolitan regions are particularly heterogeneous and have relatively large proportions of artificial surfaces. Thus, field measurements derived from nonurban areas may be inaccurate when applied to urban environments. In addition, cities dynamically change in space and time, often with an accelerated pace of change, which requires continuous measurement and monitoring. Because of variation in ecosystem and landscape structures across cities, ES indicator data derived from one urban context may not apply well to another. For this reason, urban ES studies tend to be restricted to areas where local or regional measurements have been acquired (Haase et al. 2014b). The use of land-use and land-cover based proxies will become increasingly problematic as new and understudied land-use and land-cover classes (e.g., new housing types, new open-land or built-up space arrangements, and new surface materials) emerge in cities.

In addition, we found that while land-use and land-cover based proxies can provide meaningful information across scales and enable cross-city comparisons (Larondelle et al. 2014a,b, Hamstead et al. 2016), coarse spatial and class resolution of available data may lead to over- or underestimation of ES potential. Kain et al. (2016) show how a more fine-grained representation of urban land use through service-providing elements that include both biotic and abiotic elements substantially improves the quality of ES estimates. More detailed information also enables the development of tools for planning and monitoring. For example, Kaczorowska et al. (2016) use the green area factor (GAF) as a way to monitor urban green cover. The GAF expresses the ratio of ecologically effective surface area to the total land area, wherein the particular parts of the land (a plot or block) are weighted according to the ecosystem performance and functionality they provide.

Future studies of urban ES at the city and regional levels should: (1) use high resolution data on human activities (land-use type and intensity) and urban morphology (including threedimensional representation of green and blue elements) to capture better the complexity of urban structure; (2) use standardized classification schemes for urban land cover and land use; (3) integrate land-use and land-cover data with information about people's preferences, the ways people interact with the landscape, and models that represent ecological processes; and (4) focus on understudied areas at local or neighborhood levels for gathering new field data and generating new empirically based estimates of urban ES.

\section{Insight 2: understanding relationships and mismatches}

Understanding relationships and mismatches between supply and demand for urban ES requires cross-boundary and cross-scale considerations. As functional nodes of current global networks, cities represent strategic hotspots of management and regulation, where large-scale resource exchanges occur, and where global transportation networks, commodity chains, and communication networks meet (Haase et al. 2014b). Today's teleconnected city networks exhibit mismatches between supply and demand of ES (Borgström et al. 2006, Cumming et al. 2006, Baró et al. 2015). Studies within the URBES project show that understanding urban ES supply and demand dynamics requires cross-scale and cross-boundary considerations.

Urban demand for ES such as food provision can only be fulfilled at a geographic scope that expands beyond the city boundaries (Folke et al. 1997, Gómez-Baggethun and Barton 2013). Managing these ES supply and demand relationships in urban areas may require interjurisdictional cooperation, which can be cumbersome to establish, but important for conserving and restoring ES. An analysis of the potential ES provisioning in core cities and hinterlands across Europe found that administrative boundaries are often not sufficient to delimit an area of analysis because ES supply and demand dynamics do not align with administrative boundaries (Larondelle et al. 2014a). Larondelle et al. (2014a) analyzed the regulating ES potential of $>300$ European cities at three scales: the core city within the administrative boundaries, the hinterland as defined as functional 
urban regions (OECD 2013), and the combined hinterland and core city. For most ES, the hinterlands around European cities generally had more potential to supply services such as air cooling and carbon storage than did the core city. Similar findings in Barcelona suggest that local capacity of green spaces to produce air purification and carbon sequestration in the urban core is limited. For example, greenspace within Barcelona's municipal boundaries has the potential to offset $<1 \%$ of the nitrogen dioxide $\left(\mathrm{NO}_{2}\right)$ pollution generated within city boundaries, suggesting that greenspace at a broader scale (metropolitan or regional) or measures not related to greenspace are required to abate air pollution (Baró et al. 2014).

Other ES can be supplied at a similar scale as the scale at which they are demanded. For example, the capacity to mitigate local flooding following storm events depends on the specific location, structure, and physical characteristics of the immediate environment (Andersson et al. 2015a). For the supply of cultural urban ES such as recreation and enhanced social cohesion, Camps-Calvet et al. (2016) found that multiple benefits can be supplied by small urban green areas such as urban gardens, illustrating a relatively close match between the scales of supply and demand for cultural urban ES. Kain et al. (2016) illustrate how different policy, planning, and management arrangements in Stockholm would enable the supply of urban ES to meet demand better even if overall land use remains the same. Measures systematically targeted at optimizing supply through architectural and landscape design and management can significantly increase the supply of many local-scale urban ES, including recreation, air cooling, and storm water retention.

Addressing mismatches of urban ES supply and demand requires bridging the scale at which ecological processes underpinning ES operate with the scale of management. The problem of mismatch in the scale of governance and management, and the need for cross-boundary management for successful provision of urban ES, are often cited as major barriers in the implementation of urban ES concepts in planning (Frantzeskaki and Tillie 2014) and have been identified as a potential source of conflicts related to access to, and jurisdiction of, ES (Gómez-Baggethun et al. 2013b). However, there are successful examples of cross-boundary urban ES management, as in the case of drinking water provisioning for NYC. Responsibility for ensuring safe drinking water for the population of NYC lies within municipality boundaries while the drinking water supply is drawn beyond municipal boundaries, from the Catskill-Delaware watershed, in a region to the north of NYC. Water sources, pollution abatement, and delivery and treatment infrastructure are managed by multiple agencies and stakeholders at the federal, state, regional, and city scales, constituting a form of polycentric governance of greenspace (McPhearson et al. 2014).

Future studies of urban ES at the city and regional levels should: (1) clarify the relevancy of scale, given ES management regimes and research questions (Andersson et al. 2015a); and (2) focus on the scale of both supply and demand to understand their relation to each other and the appropriate scale of governance, which in some cases may involve multiscale, multiactor mechanisms.

\section{Insight 3: mediators of urban ecosystem services}

Urban ES are mediated by nonecological elements, including physical infrastructure, technology, social practices, and the cultural contexts in which people experience human-environment relations. For the ES approach to articulate adequately ways in which ecosystems provide benefits to people in cities, it must more broadly consider the contexts within which people obtain these services (Chan et al. 2012, Andersson et al. 2015a). Because ES are benefits to humans, they are inherently generated and affected by both ecological and social processes (Andersson et al. 2007, Reyers et al. 2013). Particularly in urban ecosystems dominated by built features, urban ES are often enabled by technical elements or built infrastructure such as roof construction that can support vegetation, pipes for delivery of drinking water, and paths along green and blue corridors. ES are also mediated by a socio-political (or environmental-political) context, including governance institutions and management practices (Kronenberg 2014, Langemeyer 2015); social institutions such as norms and regulations; socioeconomic factors such as affluence or poverty that influence both the demand and the way people perceive benefit from ecosystems (Gómez-Baggethun and Kelemen 2008, Langemeyer 2015); the social-technological context, which helps to facilitate benefitting from services; and the environmental problem context (Bertram and Rehdanz 2015a, Buchel and Frantzeskaki 2015, Voigt and Wurster 2015).

Value attributed to an urban ES does not only depend on its physical characteristics, but also on the number of beneficiaries who potentially have access to that service. Because cities have high population densities (and thus high densities of beneficiaries), urban ES can present high value in small serviceproviding units (Gómez-Baggethun and Barton 2013, Villamagna et al. 2013, Elmquist et al. 2015, Zank et al. 2016). Hence, restoring, optimizing, or creating urban green spaces in dense urban areas, where relatively small quantities of additional green space can be translated into high societal benefits, can lead to increases in health and well-being of people (Bertram and Rehdanz 2015b, Elmqvist et al. 2015). Some service-providing units mitigate urban environmental problems that can arise because of high densities of people, buildings, or transportation infrastructure, and therefore, deliver a greater benefit in the presence of these problems and the related demand (Andersson et al. 2015a). For instance, the cooling influence of trees is more beneficial in neighborhoods with paved surfaces that absorb heat than in less developed areas, and the flood mitigation capability of a bioswale is more beneficial during a heavy, intense rain event than during a brief rain shower. In NYC, storm water quality enhancement is a major ES priority, given that combined sewer overflows have caused significant eutrophication of the city's tributaries and have resulted in federal fines (McPhearson et al. 2014). Likewise, air quality regulation can be very important in cities that are severely polluted (e.g., Santiago de Chile), but may be of secondary importance in cities where there are low levels of atmospheric pollution (e.g.; Helsinki; Gómez-Baggethun and Barton 2013).

Relationships among demand, supply, and benefit are not always linear. For instance, Bertram and Rehdanz (2015b) found an inverted U-shaped relationship between urban green space availability and life satisfaction among residents of densely populated, inner-city districts in Berlin. This implies that additional urban green space first increases life satisfaction but tends to decrease life satisfaction above a certain threshold. Urban ES depend on man-made infrastructure. For example, to 
understand how park infrastructure mediates the delivery of recreational services, Voigt et al. (2014) combined ecological surveys and mapping of infrastructure for both active and passive recreation with questionnaire interviews of park users in Berlin. They related specific characteristics of urban parks to ways in which parks are used and valued, finding that where there is less recreational infrastructure in Berlin, fewer park visitors engaged in recreational activities (Voigt et al. 2014). Good infrastructural accessibility, both within and outside of the boundaries of the areas of service provision, can enable uptake of urban ES.

Similarly, the value of ES can be influenced by the enviro-political context, including governance institutions and management practices as well as norms and regulations (Kronenberg 2014, Langemeyer 2015). For example, following the European Union's EU 2020 goals, many EU municipalities have enrolled in the "Covenant of Mayors" initiative, voluntarily committing to reduce their greenhouse gas emissions by at least $20 \%$ by 2020 (Baró et al. 2014), thus setting an ES demand level within an environmental problem context. Given the public good nature of carbon sequestration (and most regulating services), such policy targets to address a specific environmental problem (in this case, climate change; Baró et al. 2014) may be used as proxies for social demand of a given urban ES. If unmet demand is significant, for instance, when levels of air pollution are very high relative to targets (such as Environmental Quality Standards), green infrastructure strategies may not be an effective way to meet the targets unless they are coupled with other solutions (Baró et al. 2014, 2015). At the core city level, pollution abatement can be addressed more effectively by reducing pollution sources (e.g., by limiting traffic) rather than increasing pollution sinks (e.g., through restoration of urban green infrastructure). Thus, a mix of policy interventions and behavioral change needs to be considered when assessing future demand for urban ES (Rodríguez-Rodríguez et al. 2015).

Moreover, urban ES that require deliberate action to provide benefits also require awareness and information that can only be provided within a social context. People may ascribe higher values to service-providing units that are marketed to them or that they know to hold unique biodiversity or "high-quality" nature, even if they do not directly experience more species or "quality" than people without that knowledge (Jacobsen et al. 2008, Czajkowski and Hanley 2009). Additionally, the citizen perceptions of ES are not only linked with their socioeconomic background, as some surveys associate, but also with the experience and value sets they have from the place where they live (Buchel and Frantzeskaki 2015)

People attribute different cultural values and symbolic meanings to nature, which translate into varied beliefs, choices, and actions. For instance, park visitors may attribute the term "diverse" to a park without having precise knowledge of its biodiversity (in terms of number of species or landscape elements); rather, they use this term to articulate that they value, appreciate, or find this urban green area beautiful and worth protecting and maintaining (Voigt and Wurster 2015). Research on cultural values and symbolic meanings attributed to urban nature and on how people perceive, experience, and value it has to consider people's understanding of landscape and nature and how this understanding is grounded in their particular individual and cultural background (Voigt and Wurster 2015). Perceptions of ES are not only linked to socioeconomic background, but also with place-based experiences and value sets (Buchel and Frantzeskaki 2015). Future studies should focus on: (1) the technical-ecological interplay, with stronger consideration of the technical structures and facilities that enable ES; (2) the role of institutions in shaping and encouraging individual demand for ES; and (3) socio-cultural values that people assign to different kinds of nature, landscape elements, and species.

\section{Insight 4: cultural ecosystem services}

Cultural ES bring the diverse values and meanings people find in nature to light and enable, inform, and substantiate discussion about environmental potentials and challenges in cities. Findings from research conducted in the URBES project indicate that cultural ES stand among the most important services in urban areas (Voigt et al. 2014, Andersson et al. 2015b, Bertram and Rehdanz 2015a, Buchel and Frantzeskaki 2015, Langemeyer et al. 2015). Because people hold moral, spiritual, educational, aesthetic, place-based, and other nonmaterial values toward the urban environment, cultural ES represent many of the most intimate interactions that urbanites have with nature. Research suggests that there are strong connections among cultural ES, civic engagement, and ES stewardship (Colding and Barthel 2013, Andersson et al. 2014). Communities may support ecologically motivated management actions when those actions enhance cultural ES (Andersson et al. $2015 b$ ). Understanding the diverse ways in which people value nature creates opportunities for more inclusive valuations (Dendoncker et al. 2013) in which positive experiences are used as starting points for virtuous cycles (Krasny and Tidball 2012) that lead to enhanced cultural ES.

Research to understand cultural ES better and integrate them into ES assessments is only recently gaining ground. Still, it has become clear that cultural ES exhibit multiple levels of heterogeneity: (1) in the number and types of cultural ES, (2) in the diverse ways in which people value cultural ES, and (3) in the methods that can be used to capture these values. The number and types of experienced cultural services vary greatly depending on user perceptions, context, and culture (Bertram and Rehdanz 2015a, Buchel and Frantzeskaki 2015, Voigt and Wurster 2015, Camps-Calvet et al. 2016), which makes studying them especially challenging in urban environments characterized by high degrees of social and cultural heterogeneity (Gómez-Baggethun and Barton 2013, Kabisch et al. 2015). For instance, whereas some people may see aesthetic beauty and a form of cultural heritage in allotment gardens, others may simply see them as an eyesore. How people experience cultural ES can also depend on the location, physical setting, and structure of urban green infrastructure (Buchel and Frantzeskaki 2015, Langemeyer et al. 2015).

Urban ES also exhibit aesthetic, symbolic, and place values (Gómez-Baggethun and Barton 2013). Comparable to the cultural value and symbolic meaning of a work of art such as of Da Vinci's Mona Lisa, which is expressed neither by the entrance fee people are willing to pay to see it nor by its market value, cultural ES reflect much more than monetary values. People assign, allocate, and express diverse values and meanings to nature and its experience; these meanings and values may be different because of individual experiences and cultural backgrounds. 
Therefore, cultural ES cannot be defined without considering the particular cultural background of the people benefitting from them (Voigt 2012). For example, Voigt and Wurster (2015) interviewed residents about their perception and valuation of the diversity of an urban green space (landscape elements, species diversity). The results suggest that people's valuation of the green space as "diverse" is more related to a prevailing European idea of landscape diversity, including components such as trees, hedgerows, open spaces, and water elements (European Landscape Convention), than to their knowledge about this site.

To capture fully the multilayered complexity of urban ES values, Chan et al. (2012) discuss eight distinct value dimensions, including individual vs. holistic, physical vs. metaphysical, and process-based dimensions. For example, people might assign values to a community garden that relate to the aesthetic preferences or shared community identity of those involved in the garden. Thus far, the plurality in value dimensions is not often matched by pluralism in approaches for capturing value, which are often divided into monetary and nonmonetary (e.g., see Langemeyer et al. 2015). Although common monetary valuation methods (e.g., hedonic pricing, contingent valuation, travel cost) can be useful for capturing some aspects of the value of ES, intangible cultural ES are often not amenable to quantification and monetary metrics (Gómez-Baggethun and Barton 2013). In URBES research, methods used to evaluate intangible, nonmonetary values included questionnaires and interviews (Bertram and Rehdanz 2015a,b, Buchel and Frantzeskaki 2015, Voigt and Wurster 2015) and methods combining questionnaires with the assessment of the physical characteristics of the given area (Voigt et al. 2014, Langemeyer et al. 2015) to demonstrate the pluralism of cultural and individual values.

Cultural ES valuation methods that are interdisciplinary and involve stakeholder engagement can help to capture context and cultural differences (Kabisch et al. 2015, Langemeyer et al. 2015, Voigt and Wurster 2015). Stakeholder engagement is particularly relevant in urban land-use decision-making, characterized by trade-offs between ES and associated values, which are often conflicting and incommensurable along a single measurement axis (Langemeyer et al. 2016). To support a better integration of cultural ES into urban ES research, planning, and policy-making, we emphasize the need to develop theory and methods that accommodate value and methodological pluralism (GómezBaggethun et al. 2013a, Langemeyer et al. 2015). Possibly more than any other ES category, cultural ES are critically important to human well-being in urban areas. To be inclusive and effective, cultural ES research should concentrate on: (1) the inclusion and integration of cultural ES in urban ES assessments, (2) how plurality of values may be better captured and communicated, and (3) how different values may be integrated.

\section{Insight 5: unclear links between urban biodiversity and ecosystem services}

Links between urban biodiversity and ecosystem services remain unclear. There is limited empirical research on how biodiversity and ecosystem functioning in urban areas relate to the production of urban ES (Campbell et al. 2012, Cardinale et al. 2012, Tomimatsu et al. 2013, Harrison et al. 2014). However, we do know that biodiversity in European cities is high, often much higher than in the agricultural landscapes outside of cities because of the high degree of heterogeneity of urban ecosystems (Sukopp and Hejný 1990, Andersson et al. 2014). Urban biodiversity is generally considered fundamental to the generation of ES (Elmqvist et al. 2013). Thus, biodiversity protection and conservation should be essential components of city efforts to maintain urban ES, including regulating services that provide adaptive capacity and resilience to urban stressors such as heatwaves, hurricanes, and heavy storm spells (McPhearson et al. 2015, 2016).

However, even if biodiversity is generally considered fundamental to the generation of ES, integrating the perspective of biodiversity (and its protection) into the framework of ES research is challenging and contradictory. Where there is evidence for the importance of particular species groups as key service providers for the service provision, there are always species that seem dispensable, functionally redundant, and less effective than others (Voigt 2013, 2015). Some species even have negative effects in relation to ES, generating ecosystem disservices (GómezBaggethun and Barton 2013). Voigt $(2013,2015)$ argues that the loss of some species in a service-providing area may not have a significant negative influence or may have a positive influence on the provision of ES. Therefore, the perspective of species conservation that considers every species as unique and therefore meriting protection can be in conflict with the perspective of ES in which the functions of species are evaluated with respect to their contributions to ES. Moreover, conservation efforts are often focused on rare species, which generally have little influence on their environment because of their rarity. In contrast, from the ES perspective, the most important species for conservation are those that best support ES, which are often abundant species (Voigt 2013, 2015). Thus, both rare and abundant species contribute to the multitude of ES in a city, from social values to food web functions, so protection has to include both.

Cities are highly anthropogenic ecosystems, further challenging the ecological understanding of how novel species assemblages support urban ES. The role of particular groups of species (native, non-native, invasive) in the supply and demand for ES remains poorly understood (Haase et al. 2014b). Additionally, understanding habitat function and habitat connectivity is a key for city planners to design appropriate management and conservation strategies for urban biodiversity and ecosystem resilience, some or all of which could be vital to secure a stable supply of ES in cities (McPhearson et al. 2015). Moreover, Andersson et al. (2015a) argue that understanding cross-scale interactions and landscape diversity is needed for spatial planning and designing for ES provisioning. They further suggest that to understand the role of biodiversity in supporting different ES, it is necessary to identify the ecological level (e.g., species, communities, or ecosystems) relevant for the analysis of a given ES.

It is well known that the relicts of near-natural ecosystems are highly fragmented in urban areas, which can alter the genetic diversity and long-term survival of sensitive species dependent on this kind of ecosystem. To ensure viable populations of these species groups, urban planners will need to understand better the very specific species' needs for connectivity among suitable habitat patches. For example, the connectivity of the habitat network within the urban area plays a major role for ground-dwelling 
animal movement like for the European hedgehog in Zurich (Braaker et al. 2014) or specialist bird species (Andersson and Bodin 2009), and hence, is of primary importance for sustaining habitat services.

One of the primary difficulties in advancing urban biodiversity research is the high cost, in both time and resources, of generating new field-based biodiversity data that are essential for identifying linkages with urban ES. If cities want to make progress in understanding the links between biodiversity and urban ES, it may require significant investment at local and federal levels to support new biodiversity data collection, monitoring schemes, and empirical studies on how biodiversity affects ecosystem functioning and its outcomes in terms of services and benefits provided in different urban landscapes. At present, biodiversity research is not adequately accounted for in current funding mechanisms for urban ES-related research. Citizen-science using modern apps and smartphone technologies may provide one complementary option to support new research in this area. Still, more information on urban biodiversity is needed to understand local-, city-, and regional-scale relationships between biodiversity and the generation of urban ES (Andersson et al. 2015a, McPhearson et al. 2016).

\section{Insight 6: implementation of concepts}

Implementation of the urban ES concepts in planning and policies requires strategies that work with current methods. Since the early 2000s, multiple levels of governance in western Europe and the United States have adopted ES terminology in planning processes and resulting documents. At the EU level, examples include the European Green Infrastructure Strategy and the EU Biodiversity Strategy to 2020. At the national level, examples include the German National Strategy to Biodiversity. At the city level, examples are Berlin's Biodiversity Strategy, Barcelona's Biodiversity and Green Infrastructure Strategy, the New York State Open Space Conservation Plan, Rotterdam's Sustainability Program, the Integrated Development Strategy of Lodz 2020+, and Stockholm's Comprehensive Plan (Frantzeskaki and Tillie 2014, Giergiczny and Kronenberg 2014, Hansen et al. 2015, Kabisch 2015).

However, URBES case study research has found that there are varying ways and degrees to which the ES framework and rationale have been understood in urban planning and governance (Hansen et al. 2015, Rall et al. 2015). In URBES, the ES framework was brought to the interface of policy and science through in-depth analysis of case studies, planning documents, interviews, and workshops with officials from urban planning administrations (Frantzeskaki and Tillie 2014, Hansen et al. 2015, Kabisch 2015, Rall et al. 2015, Kaczorowska et al. 2016, Kain et al. 2016). Researchers identified main challenges concerning the understanding, operationalization, and implementation of the ES framework in urban environmental planning.

One barrier slowing down the implementation of the ES framework and biodiversity planning into urban policy and practice is the science-policy gap. In all seven URBES case study cities, we found that the wealth of scientific knowledge available reaches policy makers and practitioners only to a limited extent. Factors that contribute to the lack of information transfer include the terminological complexity of the ES framework, the weak connection of the framework to policy problems, and asynchrony between the adaptive policy-making processes in cities and the timing when research inputs become available to be applied in planning (Frantzeskaki and Tillie 2014, Hansen et al. 2015, Kabisch 2015, Kaczorowska et al. 2016). Other factors such as time and financial constraints, as well as the presentation of scientific results formats incomprehensible or unusable to planners (e.g., publication in nonopen-access journals), are not necessarily related to the ES concept but highlight a general problem of knowledge transfer between science and policy and planning.

In principle, the ES concept could provide a language bridge between scholars and practitioners in different sectors and cities. However, the URBES project findings indicate that there is wide variation in the use of the terminology. For instance, results from the case study in Berlin showed that stakeholders use the background principles of the ES concept and relevant indicators but do not explicitly link this to the ES concept. When asked to define the term ES, stakeholders primarily associated the term with monetization of natural elements, rather than broader benefits that humans gain from nature. The term ES was also related to the less anthropocentric-oriented concept of landscape functions (Kabisch 2015). Findings from an NYC-based case study indicate that the ES concept is present in planning documents, though description of the concept is limited to a general idea of communicating benefits that nature provides to humans. Similar terms such as environmental services or benefits appear interchangeably (Hansen et al. 2015). Stakeholder interviews revealed that this concept, in combination with the development and implementation of recent, more integrated strategic plans, has helped different city agencies and stakeholders to communicate and work together toward shared goals (Rall et al. 2015). In Stockholm, which has a long history of addressing issues of biodiversity and cultural landscapes, many stakeholders showed interest in the somewhat "hyped" ES concept as a potentially useful tool for safeguarding urban ecosystems in the context of intense urban growth, but found it too theoretical and complex to be adopted easily for use in their work (Kaczorowska et al. 2016).

A second challenge concerns the demand by stakeholders for ES assessment tools or models. In NYC, planners asked for more complex ES assessment models that incorporate more of the local context but are still scalable to the neighborhood level. These models would ideally integrate both functional and social assessment (i.e., supply and demand). There is also increasing awareness of and interest by green space planners and managers in NYC in incorporating community perceptions and values of green space (Rall et al. 2015). Linking to existing planning concepts such as multifunctionality can provide an entry point for integrating the ES concept into urban greening and green infrastructure planning (Hansen and Pauleit 2014). Although some stakeholders are demanding more complex models or tools that can address specific needs, the concept, terminology, and specific valuation methods used by scholars to assess ES may be too complex for many urban stakeholders. Such studies can, nevertheless, provide general information on the importance of nature as perceived by city inhabitants, rather than specific information that might be easily incorporated into traditional decision-making processes (Giergiczny and Kronenberg 2014). Still, Stockholm stakeholders identified an urgent need for the ES 
concept to be made more useful in relation to practical tools used for detailed planning and land allocation agreements in ongoing urban development projects (Kaczorowska et al. 2016). Interactions between scientists and urban planners in the case study cities enhanced urban stakeholders' perceptions of the urban ES framework. In particular, spatial visualization of urban ES through land-use maps, as well as through charts and diagrams showing urban ES values, proved to be a powerful tool for helping to understand and communicate the ES concept and related values (Kain et al. 2016).

For further integration of the urban ES framework into urban policy and planning, we recommend that complex scientific terminology be translated in a way that is understandable for urban stakeholders. This can be facilitated by usable tools such as maps that highlight the distribution and values of urban ES based on a land use. However, such maps should be provided in formats compatible with the conventions of respective local planning systems (Kain et al. 2016). From our experience in the URBES cities, we propose that communication of ES to policy makers and practitioners should minimize the use of acronyms and complex jargon. When possible, communication should draw on related concepts that are well established in urban policy and planning. Finally, language to communicate urban ES should be adapted for its audience. The explicit use of the ES concept may not be necessary as long as links are drawn between urban ecosystems and human well-being. Hybrid concepts, existing in the planning and ES domains, can help to bridge disciplines and create stronger links between science and practice. For example, the term "natural capital" may work well to communicate with economists in policy contexts such as environmental accounting, whereas the term "urban green infrastructure" may be more suitable to communicate with urban architects and engineers.

\section{Insight 7: need for cross-city comparisons}

Cross-city comparisons are fundamental for understanding the drivers of ecosystem structure, functioning, and processes. Crosscity comparisons are fundamental to advancing the understanding of drivers of urban ecosystem structure and function, to differentiate between dynamics of urban ES that are locally unique in cities and patterns and processes, which are potentially generalizable to multiple urban contexts (McPhearson et al. 2016). We expect local contexts and dynamics always to be important for explaining patterns and processes within cities and urban regions (Niemelä and Kotze 2009); however, we also expect that some principles may generally apply to all urban systems or to a set or type of urban systems. Cross-city, cross-context research that employs similar research approaches in multiple urban areas allows identifying similarities and differences in the drivers of urban ES while building research collaborations and facilitating knowledge transfer. Systematic cross-city comparison studies could also help to conduct estimations of urban biodiversity and ES at regional to global scales to elucidate global trends (Kabisch and Haase 2013, Larondelle and Haase 2013, Larondelle et al. 2014a) and inform management and governance. For example, the potential benefits of street trees for improving urban air quality, temperature, and consequently, public health has generated major efforts of urban tree plantings such as New York's million trees program (McPhearson 2011, McPhearson et al. 2013b). However, these benefits strongly depend on the urban context, are not necessarily generalizable to all situations
(Kronenberg 2015), and may have no effect on urban public health and well-being (Pataki et al. 2011).

Experiences from the URBES project shows that cross-city comparisons help: (1) to evaluate and establish thresholds for urban ES supply in comparison to the demand dynamics and relationships (Baró et al. 2015); (2) to uncover good practices in urban ES implementation and planning (Hansen et al. 2015); (3) to support scientific understanding of how different urban landcover combinations affect the provision of urban ES, in particular urban heat mitigation (Larondelle et al. 2014a, Hamstead et al. 2016); (4) to advance understanding of similar social requirements and needs for effective use of urban ES despite differences in cities, cultural backgrounds, and other factors (e.g., facilities to support recreation, accessibility by public transit, and more; McPhearson et al. 2013b, Voigt et al. 2014, Andersson et al. 2015a); (5) to establish uniform terminology, language, and wording to move urban ES research and practice forward across contexts and cities (Gomez-Baggethun et al. 2013a); and (6) to improve knowledge on common urban ES demand, which is much less understood and much less investigated than urban ES supply.

A potential benefit of the urban ES framework is that it provides a solution to the problem of comparing ecological data and analytical findings regarding the benefits of ecosystems across cities. However, this requires further development of an agreed set of methodologies for comparative assessment of ES. Through land-use intensification processes, urban landscapes tend to be heterogeneous over fine spatial scales relative to nonurban landscapes. As a consequence, it can be a challenge to compare the ecological benefits of sites between cities, or even within a single city. The concept of ES providing and reducing elements can form a basis for operationalizing nonmonetary or monetary assessment of urban ES on a site level (Wurster and Artmann 2014, Baró et al. 2015). In this sense, ES can be seen as common denominators that can be used to compare benefits provided by sites, even if those sites have different landscape features, infrastructure characteristics, or are in different cultural contexts (Kabisch et al. 2015).

Comparative research has begun to make progress in informing local management of urban biodiversity and ecological functioning (Haase et al. 2014a, Larondelle et al. 2014a). However, to develop design principles, urban ecosystem management guidelines, and provide input to decision-making on urban ES that is based on a broad evidence base, it would be highly beneficial to develop a cross-city comparative research program for advancing the ability to provide general knowledge on urban ecosystem patterns and processes (Niemelä et al. 2010). Such a comparative program could allow the contrast of research results at different scales toward the development of confirmed generalizations regarding multiple kinds of urban relationships such as between ES and urban form, structure, and function (Larondelle et al. 2014a). Such research should use a common conceptual framework, use similar and comparable methods and data, and ask similar questions. Standard research methodologies addressing similar research questions could be applied to multiple urban areas, adopting already proven successful comparative approaches (Larondelle et al. 2014a, Baró et al. 2015). 


\section{CONCLUSION: ENABLING COMMENSURABILITY OR A TOWER OF BABEL?}

As fundamentally built on value pluralism, the concept of urban ES can provide an inclusive platform for discursive governance, cocreation of knowledge, and stakeholder involvement in the elicitation of urban ES values. The ES framework can provide a common language through which scholars, policy makers, and practitioners in interdisciplinary fields can bring together knowledge from different contexts and disciplinary domains. The ES framework holds the potential to conceive of cities and their hinterlands as interconnected ES landscapes in which many ES are comanaged (Andersson et al. 2015b). Different kinds of approaches are needed to measure and value ES for this purpose. However, as findings from the URBES project indicate, it can be challenging to apply multiple methods and link diverse approaches through the larger theoretical framework, and even more so to communicate this information in formats that can be readily used by decision makers and planners. As new efforts to develop green infrastructure and nature-based solutions for urban sustainability and resilience in cities continue to emerge, urban ES can be a way to capture different values of nature in cities for cities, their citizens, and the variety of stakeholders within and beyond city boundaries. Building bridges to overcome the various gaps, inconsistencies, and incommensurability associated with the study of urban ES are of particular importance for future research.

Incompatible theoretical frameworks, methods, and research traditions, as well as insufficient data, can inhibit integration of crucial knowledge. For example, although we recognize biodiversity as a key issue fundamental to the establishment of the urban ES concept and its operationalization, we struggle with the integration and inclusion of actual biodiversity research. To overcome this knowledge gap, we need to define and analytically relate to biodiversity in new ways that connect more directly to urban ES, e.g., through functional traits.

In addition, spatial associations such as those between potential supply and demand are understudied in urban ES assessments. They could offer a direct hands-on tool for urban planning and design at all scales, and promote collaborative approaches. Socialecological interpretation of landscape ecology, urban morphology, and socioeconomic patterns has not yet reached the full integration needed to address ES, and will need to expand further to include technical and infrastructure dimensions of urban ES production (McPhearson et al. 2016).

Future research should continue to develop methods for integrated assessment and valuation of urban ES from both natural and social sciences. This is particularly important for cultural urban ES valuation in which plurality of values is most prominent, offering a promising avenue to capture their societal importance and actively engage urban stakeholders. By necessity, this means that urban ES researchers should make stronger connections to social science as well as to the planning and governance communities.

Multicity and cross-scale comparisons are essential to the development of the general theories of urban ES. Multiple valuation methods are needed to address the multiple perspectives of urban green space value. Testing these multiple methods in a similar way in different cities may allow a generalizable understanding of how values for different types of urban green spaces vary across cities.

Finally, urban ES frameworks have great potential to serve as a bridge between science and policy in the context of urban planning and environmental governance. Knowledge translation and coproduction mediation processes and tools need to be created in a systematic way based on a transdisciplinary ground. Particular attention should be given to the multiplicity of stakeholder backgrounds, perceptions, expectations, and application contexts. The appropriate level of complexity of scientific knowledge that is introduced into planning and governance processes depends on local circumstances. Successful applications require tailoring the scientific processes to fit social and political processes and address scale and boundary mismatches.

Responses to this article can be read online at: http://www.ecologyandsociety.org/issues/responses. $\mathrm{php} / 8445$

\section{Acknowledgments:}

This research was funded by the ERA-Net BiodivERsA as part of the URBES project (2011-2014), and the national funding bodies contributing to the ERANET fund.

\section{LITERATURE CITED}

Andersson, E., S. Barthel, and K. Ahrné. 2007. Measuring socialecological dynamics behind the generation of ecosystem services. Ecological Applications 17(5):1267-1278. http://dx.doi. org/10.1890/06-1116.1

Andersson, E., S. Barthel, S. Borgström, J. Colding, T. Elmqvist, C. Folke, and Å. Gren. 2014. Reconnecting cities to the biosphere: stewardship of green infrastructure and urban ecosystem services. Ambio 43(4):445-453. http://dx.doi.org/10.1007/s13280-014-0506y

Andersson, E., and Ö. Bodin. 2009. Practical tool for landscape planning? An empirical investigation of network based models of habitat fragmentation. Ecography 32(1):123-132. http://dx.doi. org/10.1111/j.1600-0587.2008.05435.X

Andersson, E., T. McPhearson, P. Kremer, E. Gomez-Baggethun, D. Haase, M. Tuvendal, and D. Wurster. 2015a. Scale and context dependence of ecosystem service providing units. Ecosystem Services 12:157-164. http://dx.doi.org/10.1016/j.ecoser.2014.08.001

Andersson, E., M. Tengö, T. McPhearson, and P. Kremer. $2015 b$. Cultural ecosystem services as a gateway for improving urban sustainability. Ecosystem Services 12:165-168. http://dx.doi. org/10.1016/j.ecoser.2014.08.002

Baró, F., L. Chaparro, E. Gómez-Baggethun, J. Langemeyer, D. J. Nowak, and J. Terradas. 2014. Contribution of ecosystem services to air quality and climate change mitigation policies: the case of urban forests in Barcelona, Spain. Ambio 43(4):466-479. http://dx.doi.org/10.1007/s13280-014-0507-x 
Baró, F., D. Haase, E. Gómez-Baggethun, and N. Frantzeskaki. 2015. Mismatches between ecosystem services supply and demand in urban areas: a quantitative assessment in five European cities. Ecological Indicators 55:146-158. http://dx.doi. org/10.1016/j.ecolind.2015.03.013

Bertram, C., and K. Rehdanz. 2015a. Preferences for cultural urban ecosystem services: comparing attitudes, perception, and use. Ecosystem Services 12:187-199. http://dx.doi.org/10.1016/j. ecoser.2014.12.011

Bertram, C., and K. Rehdanz. 2015b. The role of urban green space for human well-being. Ecological Economics 120:139-152. http://dx.doi.org/10.1016/j.ecolecon.2015.10.013

Borgström, S. T., T. Elmqvist, P. Angelstam, and C. AlfsenNorodom. 2006. Scale mismatches in management of urban landscapes. Ecology and Society 11(2):16. [online] URL: http:// www.ecologyandsociety.org/vol11/iss2/art16/

Braaker, S., J. Ghazoul, M. K. Obrist, and M. Moretti. 2014. Habitat connectivity shapes urban arthropod communities: the key role of green roofs. Ecology 95(4):1010-1021. http://dx.doi. org/10.1890/13-0705.1

Buchel, S., and N. Frantzeskaki. 2015. Citizens'voice: a case study about perceived ecosystem services by urban park users in Rotterdam, The Netherlands. Ecosystem Servcies 12:169-177. http://dx.doi.org/10.1016/j.ecoser.2014.11.014

Campbell, A. J., J. C. Biesmeijer, V. Varma, and F. L. Wäckers. 2012. Realising multiple ecosystem services based on the response of three beneficial insect groups to floral traits and trait diversity. Basic and Applied Ecology 13(4):363-370. http://dx.doi. org/10.1016/j.baae.2012.04.003

Camps-Calvet, M., J. Langemeyer, L. Calvet-Mir, and E. GómezBaggethun. 2016. Ecosystem services provided by urban gardens in Barcelona, Spain: insights for policy and planning. Environmental Science and Policy, in press. http://dx.doi. org/10.1016/j.envsci.2016.01.007

Cardinale, B. J., J. E. Duffy, A. Gonzalez, D. U. Hooper, C. Perrings, P. Venail, A. Narwani, G. M. Mace, D. Tilman, D. A. Wardle, A. P. Kinzig, G. C. Daily, M. Loreau, J. B. Grace, A. Larigauderie, D. S. Srivastava, and S. Naeem. 2012. Biodiversity loss and its impact on humanity. Nature 486(7401):59-67. http:// dx.doi.org/10.1038/nature11148

Chan, K. M. A., T. Satterfield, and J. Goldstein. 2012. Rethinking ecosystem services to better address and navigate cultural values. Ecological Economics 74:8-18. http://dx.doi.org/10.1016/j. ecolecon.2011.11.011

Colding, J., and S. Barthel. 2013. The potential of "Urban Green Commons" in the resilience building of cities. Ecological Economics 86:156-166. http://dx.doi.org/10.1016/j.ecolecon.2012.10.016

Cumming, G. S., D. H. M. Cumming, and C. L. Redman. 2006. Scale mismatches in social-ecological systems: causes, consequences, and solutions. Ecology And Society 11(1):14. [online] URL: http://www.ecologyandsociety.org/vol11/iss1/ $\underline{\operatorname{art14}}$

Czajkowski, M., and N. Hanley. 2009. Using labels to investigate scope effects in stated preference methods. Environmental and Resource Economics 44(4):521. http://dx.doi.org/10.1007/s10640-009-9299-
Dendoncker, N., H. Keune, S. Jacobs, and E. Gómez-Baggethun. 2013. Inclusive ecosystem services valuation. Pages 3-12 in $\mathrm{S}$. Jacobs, N. Dendoncker, and H. Keune, editors. Ecosystem services: global issues, local practices. Elsevier, Amsterdam, The Netherlands. http://dx.doi.org/10.1016/b978-0-12-419964-4.00001-9

Elmqvist, T., M. Fragkias, J. Goodness, B. Güneralp, P. Marcotullio, R. I. McDonald, S. Parnell, M. Schewenius, M. Sendstad, K. C. Seto, and C. Wilkinson, editors. 2013. Urbanization, biodiversity and ecosystem services: challenges and opportunities: a global assessment. Springer, Dordrecht, The Netherlands. http://dx.doi.org/10.1007/978-94-007-7088-1

Elmqvist, T., H. Setälä, S. N. Handel, S. van der Ploeg, J. Aronson, J. N. Blignaut, E. Gómez-Baggethun, D. J. Nowak, J. Kronenberg, and R. de Groot. 2015. Benefits of restoring ecosystem services in urban areas. Current Opinion in Environmental Sustainability 14:101-108. http://dx.doi.org/10.1016/j.cosust.2015.05.001

Folke, C., A. Jansson, J. Larsson, and R. Costanza. 1997. Ecosystem appropriation by cities. Ambio 26(3):167-172. [online] URL: http://www.jstor.org/stable/4314576

Frantzeskaki, N., and N. Tillie. 2014. The dynamics of urban ecosystem governance in Rotterdam, The Netherlands. Ambio 43 (4):542-555. http://dx.doi.org/10.1007/s13280-014-0512-0

Giergiczny, M., and J. Kronenberg. 2014. From valuation to governance: using choice experiment to value street trees. Ambio 43(4):492-501. http://dx.doi.org/10.1007/s13280-014-0516-9

Gómez-Baggethun, E., and D. N. Barton. 2013. Classifying and valuing ecosystem services for urban planning. Ecological Economics 86:235-245. http://dx.doi.org/10.1016/j.ecolecon.2012.08.019

Gomez-Baggethun, E., Å. Gren, D. N. Barton, T. McPhearson, P. O'Farrell, E. Andersson, Z. Hampstead, and P. Kremer. $2013 a$. Urban ecosystem services. Pages 175-251 in T. Elmqvist, M. Fragkias, J. Goodness, B. Güneralp, P. J. Marcotullio, R. I. McDonald, S. Parnell, M. Schewenius, M. Sendstad, K. C. Seto, and C. Wilkinson, editors. Urbanization, biodiversity and ecosystem services: challenges and opportunities: a global assessment. Springer, Dordrecht, The Netherlands. http://dx.doi. org/10.1007/978-94-007-7088-1 11

Gómez-Baggethun, E., and E. Kelemen. 2008. Linking institutional change and the flows of ecosystem services. Case studies from Spain and Hungary. Pages 118-145 in T. KluvánkováOravská, V. Chobotova, J. Jílková, and P. Sauer, editors. Institutional analysis of sustainability problems: emerging theories and methods in sustainability research. Nakladatelství a vydavatelství litomyšlského semináre, Prague, Czech Republic.

Gómez-Baggethun, E., E. Kelemen, B. Martín-López, I. Palomo, and C. Montes. 2013b. Scale misfit in ecosystem service governance as a source of environmental conflict. Society and Natural Resources 26(10):1202-1216. http://dx.doi. org/10.1080/08941920.2013.820817

Haase, D., N. Frantzeskaki, and T. Elmqvist. 2014a. Ecosystem services in urban landscapes: practical applications and governance implications. Ambio 43(4):407-412. http://dx.doi. org/10.1007/s13280-014-0503-1

Haase, D., N. Larondelle, E. Andersson, M. Artmann, S. Borgström, J. Breuste, E. Gomez-Baggethun, Å. Gren, Z. 
Hamstead, R. Hansen, N. Kabisch, P. Kremer, J. Langemeyer, E. L. Rall, T. McPhearson, S. Pauleit, S. Qureshi, N. Schwarz, A. Voigt, D. Wurster, and T. Elmqvist. 2014b. A quantitative review of urban ecosystem service assessments: concepts, models, and implementation. Ambio 43(4):413-433. http://dx.doi.org/10.1007/ s13280-014-0504-0

Hamstead, Z. A., P. Kremer, N. Larondelle, T. McPhearson, and D. Haase. 2016. Classification of the heterogeneous structure of urban landscapes (STURLA) as an indicator of landscape function applied to surface temperature in New York City. Ecological Indicators, in press. http://dx.doi.org/10.1016/j. ecolind.2015.10.014

Hansen, R., N. Frantzeskaki, T. McPhearson, E. Rall, N. Kabisch, A. Kaczorowska, J.-H. Kain, M. Artmann, and S. Pauleit. 2015. The uptake of the ecosystem services concept in planning discourses of European and American cities. Ecosystem Services 12:228-246. http://dx.doi.org/10.1016/j.ecoser.2014.11.013

Hansen, R., and S. Pauleit. 2014. From multifunctionality to multiple ecosystem services? A conceptual framework for multifunctionality in green infrastructure planning for urban areas. Ambio 43(4):516-529. http://dx.doi.org/10.1007/s13280-014-0510-2

Harrison, P. A., P. M. Berry, G. Simpson, J. R. Haslett, M. Blicharska, M. Bucur, R. Dunford, B. Egoh, M. Garcia-Llorente, N. Geamănă, W. Geertsema, E. Lommelen, L. Meiresonne, and F. Turkelboom. 2014. Linkages between biodiversity attributes and ecosystem services: a systematic review. Ecosystem Services 9:191-203. http://dx.doi.org/10.1016/j.ecoser.2014.05.006

Jacobsen, J. B., J. H. Boiesen, B. J. Thorsen, and N. Strange. 2008. What's in a name? The use of quantitative measures versus 'Iconised' species when valuing biodiversity. Environmental and Resource Economics 39(3):247-263. http://dx.doi.org/10.1007/ $\underline{\text { s10640-007-9107-6 }}$

Kabisch, N. 2015. Ecosystem service implementation and governance challenges in urban green space planning - the case of Berlin, Germany. Land Use Policy 42:557-567. http://dx.doi. org/10.1016/j.landusepol.2014.09.005

Kabisch, N., and D. Haase. 2013. Green spaces of European cities revisited for 1990-2006. Landscape and Urban Planning 110:113-122. http://dx.doi.org/10.1016/j.landurbplan.2012.10.017

Kabisch, N., S. Qureshi, and D. Haase. 2015. Humanenvironment interactions in urban green spaces - a systematic review of contemporary issues and prospects for future research. Environmental Impact Assessment Review 50:25-34. http://dx.doi. org/10.1016/j.eiar.2014.08.007

Kaczorowska, A., J.-H. Kain, J. Kronenberg, and D. Haase. 2016. Ecosystem services in urban land use planning: integration challenges in complex urban settings - case of Stockholm. Ecosystem Services, in press. http://dx.doi.org/10.1016/j. ecoser.2015.04.006

Kain, J.-H., N. Larondelle, D. Haase, and A. Kaczorowska. 2016. Exploring local consequences of two land-use alternatives for the supply of urban ecosystem services in Stockholm year 2050. Ecological Indicators, in press. http://dx.doi.org/10.1016/j. ecolind.2016.02.062
Krasny, M. E., and K. G. Tidball. 2012. Civic ecology: a pathway for Earth stewardship in cities. Frontiers in Ecology and the Environment 10(5):267-273. http://dx.doi.org/10.1890/110230

Kronenberg, J. 2014. Environmental impacts of the use of ecosystem services: case study of birdwatching. Environmental Management 54(3):617-630. http://dx.doi.org/10.1007/s00267-014-0317-8

Kronenberg, J. 2015. Why not to green a city? Institutional barriers to preserving urban ecosystem services. Ecosystem Services 12:218-227. http://dx.doi.org/10.1016/j.ecoser.2014.07.002

Langemeyer, J. 2015. Urban ecosystem services: the value of green spaces in cities. Stockholm University, Stockholm, Sweden.

Langemeyer, J., F. Baró, P. Roebeling, and E. Gómez-Baggethun. 2015. Contrasting values of cultural ecosystem services in urban areas: the case of park Montjuïc in Barcelona. Ecosystem Services 12:178-186. http://dx.doi.org/10.1016/j.ecoser.2014.11.016

Langemeyer, J., E. Gómez-Baggethun, D. Haase, S. Scheuer, and T. Elmqvist. 2016. Bridging the gap between ecosystem service assessments and land-use planning through Multi-Criteria Decision Analysis (MCDA). Environmental Science and Policy, in press. http://dx.doi.org/10.1016/j.envsci.2016.02.013

Larondelle, N., and D. Haase. 2013. Urban ecosystem services assessment along a rural-urban gradient: a cross-analysis of European cities. Ecological Indicators 29:179-190. http://dx.doi. org/10.1016/j.ecolind.2012.12.022

Larondelle, N., D. Haase, and N. Kabisch. 2014a. Mapping the diversity of regulating ecosystem services in European cities. Global Environmental Change 26:119-129. http://dx.doi. org/10.1016/j.gloenvcha.2014.04.008

Larondelle, N., Z. A. Hamstead, P. Kremer, D. Haase, and T. McPhearson. 2014b. Applying a novel urban structure classification to compare the relationships of urban structure and surface temperature in Berlin and New York City. Applied Geography 53:427-437. http://dx.doi.org/10.1016/j.apgeog.2014.07.004

McPhearson, P. T. 2011. Toward a sustainable New York City: greening through urban forest restoration. Pages 181-204 in M. I. Slavin, editor. Sustainability in America's cities: creating the green metropolis. Island Press and Center for Resource Economics, Washington, D.C., USA. http://dx.doi. org/10.5822/978-1-61091-028-6 9

McPhearson, T., E. Andersson, T. Elmqvist, and N. Frantzeskaki. 2015. Resilience of and through urban ecosystem services. Ecosystem Services 12:152-156. http://dx.doi.org/10.1016/j. ecoser.2014.07.012

McPhearson, T., Z. A. Hamstead, and P. Kremer. 2014. Urban ecosystem services for resilience planning and management in New York City. Ambio 43(4):502-515. http://dx.doi.org/10.1007/ s13280-014-0509-8

McPhearson, T., P. Kremer, and Z. A. Hamstead. 2013a. Mapping ecosystem services in New York City: applying a social-ecological approach in urban vacant land. Ecosystem Services 5:11-26. http://dx.doi.org/10.1016/j.ecoser.2013.06.005

McPhearson, T., D. Maddox, B. Gunther, and D. Bragdon. $2013 b$. Local assessment of New York City: biodiversity, green space, 
and ecosystem services. Pages 355-383 in T. Elmqvist, M. Fragkias, J. Goodness, B. Güneralp, P. J. Marcotullio, R. I. McDonald, S. Parnell, M. Schewenius, M. Sendstad, K. C. Seto, and C. Wilkinson, editors. Urbanization, biodiversity and ecosystem services: challenges and opportunities: a global assessment. Springer, Dordrecht, The Netherlands. http://dx.doi. org/10.1007/978-94-007-7088-1 19

McPhearson, T., S. T. A. Pickett, N. B. Grimm, J. Niemelä, M. Alberti, T. Elmqvist, C. Weber, D. Haase, J. Breuste, and S. Qureshi. 2016. Advancing urban ecology toward a science of cities. BioScience 66(3):198-212. http://dx.doi.org/10.1093/biosci/ $\underline{\text { biw002 }}$

Niemelä, J., and D. J. Kotze. 2009. Carabid beetle assemblages along urban to rural gradients: a review. Landscape and Urban Planning 92(2):65-71. http://dx.doi.org/10.1016/j.landurbplan.2009.05.016

Niemelä, J., S.-R. Saarela, T. Söderman, L. Kopperoinen, V. YliPelkonen, S. Väre, and D. J. Kotze. 2010. Using the ecosystem services approach for better planning and conservation of urban green spaces: a Finland case study. Biodiversity and Conservation 19(11):3225-3243. http://dx.doi.org/10.1007/s10531-010-9888-8

OECD (Organisation for Economic Co-operation and Development). 2013. Definition of functional urban areas (FUA) for the OECD metropolitan database. OECD Definitions. OECD, Paris, France. [online] URL: http://www.oecd.org/gov/regionalpolicy/Definition-of-Functional-Urban-Areas-for-the-OECDmetropolitan-database.pdf

Pataki, D. E., M. M. Carreiro, J. Cherrier, N. E. Grulke, V. Jennings, S. Pincetl, R. V. Pouyat, T. H. Whitlow, and W. C. Zipperer. 2011. Coupling biogeochemical cycles in urban environments: ecosystem services, green solutions, and misconceptions. Frontiers in Ecology and the Environment 9 (1):27-36. http://dx.doi.org/10.1890/090220

Rall, E. L., N. Kabisch, and R. Hansen. 2015. A comparative exploration of uptake and potential application of ecosystem services in urban planning. Ecosystem Services 16:230-242. http:// dx.doi.org/10.1016/j.ecoser.2015.10.005

Reyers, B., R. Biggs, G. S. Cumming, T. Elmqvist, A. P. Hejnowicz, and S. Polasky. 2013. Getting the measure of ecosystem services: a social-ecological approach. Frontiers in Ecology and the Environment 11(5):268-273. http://dx.doi.org/10.1890/120144

Rodríguez-Rodríguez, D., J. H. Kain, D. Haase, F. Baró, and A. Kaczorowska. 2015. Urban self-sufficiency through optimised ecosystem service demand. A utopian perspective from European cities. Futures 70:13-23. http://dx.doi.org/10.1016/j.futures.2015.03.007

Sukopp, H., and S. Hejný. 1990. Urban ecology: plants and plant communities in urban environments. SPB Academic, Amsterdam, The Netherlands.

Tomimatsu, H., T. Sasaki, H. Kurokawa, J. R. Bridle, C. Fontaine, J. Kitano, D. B. Stouffer, M. Vellend, T. M. Bezemer, T. Fukami, E. A. Hadly, M. G. A. van der Heijden, M. Kawata, S. Kéfi, N. J. B. Kraft, K. S. McCann, P. J. Mumby, T. Nakashizuka, O. L. Petchey, T. N. Romanuk, K. N. Suding, G. Takimoto, J. Urabe, and S. Yachi. 2013. Sustaining ecosystem functions in a changing world: a call for an integrated approach. Journal of Applied Ecology 50(5):1124-1130. http://dx.doi.org/10.1111/1365-2664.12116
Villamagna, A. M., P. L. Angermeier, and E. M. Bennett. 2013. Capacity, pressure, demand, and flow: a conceptual framework for analyzing ecosystem service provision and delivery. Ecological Complexity 15:114-121. http://dx.doi.org/10.1016/j.ecocom.2013.07.004

Voigt, A. 2012. Landscapes as ecosystems. What is lost when science gains the privilege of interpretation? Pages 99-102 in I. Dymitryszyn, M. Kaczyńska, and G. Maksymiuk, editors. The power of landscape: peer reviewed proceedings of ECLAS 2012 conference at Warsaw University of Life Sciences. Warsaw University of Life Sciences, Warsaw, Poland.

Voigt, A. 2013. Naturschutz nur für Leistungsträger? Überlegungen zu der Frage, inwiefern das Konzept der Ecosystem Services zum Schutz der Biodiversität beitragen kann. Pages 141-157 in J. Friedrich, A. Halsband, and L. Minkmar, editors. Societal dimensions of the conservation and utilization of biological diversity. University of Göttingen, Göttingen, Germany.

Voigt, A. 2015. Die Macht des Ökonomischen im Blick auf Natur und Landschaft: Eine Diskussion des Ökosystemdienstleistungsansatzes. Pages 201-219 in S. Kost and A. Schönwald, editors. Landschaftswandel - Wandel von Machtstrukturen. Springer, Wiesbaden, Germany. http://dx.doi.org/10.1007/978-3-658-04330-8 13

Voigt, A., N. Kabisch, D. Wurster, D. Haase, and J. Breuste. 2014. Structural diversity: a multi-dimensional approach to assess recreational services in urban parks. Ambio 43(4):480-491. http:// dx.doi.org/10.1007/s13280-014-0508-9

Voigt, A., and D. Wurster. 2015. Does diversity matter? The experience of urban nature's diversity: case study and cultural concept. Ecosystem Services 12:200-208. http://dx.doi.org/10.1016/ j.ecoser.2014.12.005

Wurster, D., and M. Artmann. 2014. Development of a concept for non-monetary assessment of urban ecosystem services at the site level. Ambio 43(4):454-465. http://dx.doi.org/10.1007/ s13280-014-0502-2

Zank, B., K. J. Bagstad, B. Voigt, and F. Villa. 2016. Modeling the effects of urban expansion on natural capital stocks and ecosystem service flows: a case study in the Puget Sound, Washington, USA. Landscape and Urban Planning 149:31-42. http://dx.doi.org/10.1016/j.landurbplan.2016.01.004 